\title{
Closing Remarks
}

I do not intend to end this book with a synthesis of Austromarxist theory and practice as understood by Otto Bauer. The most important reasons are the following. Firstly, Bauer's theoretical legacy comprises a number of different scientific disciplines. In his work, they maintain a relatively autonomous character. Consequently, I treated them as self-contained areas of study in my reconstruction, while striving to flesh out the motifs they had in common that is, the defence of individual freedom, and democracy as an autotelic value of paramount importance for the entire organisation of social and political life. Secondly, it is impossible to reveal the epistemological value of individual theories by analysing the theses they encompass. This can only be done by relating these ideas to the influential intellectual and political tendencies of the time. Wherever Bauer's ideas were linked to the political practice of the Social-Democratic movement, I presented their connection to concrete sociopolitical issues and the relevant historical and social conditions. Thirdly, but no less importantly, I ended each chapter of this book with conclusions and appraisals.

Instead of a summary, I will therefore offer a few general remarks on Bauer's contribution to socialist theory. That is to say, I will highlight where he contradicted Marxian ideas that could no longer be applied to the socio-political realities of Bauer's lifetime. I will also briefly comment on the political strategy and tactics he adopted for the SDAP.

Otto Bauer, a legend when he was still alive, remains a controversial figure posthumously. His work is distinguished by his outstanding personality and intense, critical mind. Literature dedicated to Bauer tends to emphasise his great achievements as a historian, sociologist, and political scientist in four areas: the social and economic history of Austria, studies on the nation and nationalism, the analysis of the Russian Revolution and Bolshevism, and interpretations of fascism. ${ }^{1}$ Although this appraisal is entirely justified, I would like to complement it further by drawing attention to a number of issues that were essential to Bauer's contribution:

- In light of the dominant positions in the Second International, his proposals for the national question and socialist revolution, the state, and especially democracy, were innovative. Bauer's emphasis on the axiological value of democracy and its role in civil society appears especially valuable to me.

1 See, for example, Hanisch 1985, p. 195.

(C) EWA CZERWIŃSKA-SCHUPP, 2017 | DOI: 10.1163/9789004325838_010

This is an open access article distributed under the terms of the CC-BY-NC License.

Ewa CŻerwińska-Schupp - 9789004325838 
- Bauer determinedly settled scores with Lenin's interpretation of Marx's historical materialism and the Bolshevik method of building socialism.

- His vision of a future state, his programme for cultural autonomy, his socialisation and agrarian programme, and his theory of 'integral socialism', which are associated with him today, were all original contributions to the evolution of Marxist and socialist theory.

- His proposals concerning the socio-political and democratic system were remarkable.

There is yet another aspect to Bauer's theoretical input which usually escapes the attention of historians and political scientists. Although he invariably asserted his loyalty to Marxism, Bauer remained an independent thinker who was far from blind to changing realities. Hence his texts contain ideas strongly rooted in Marxist dogma, but also attempt to break free from such strictures. This tension in Bauer's thinking was particularly manifested in his consistent attempts to incorporate the subjective and evaluative aspect into the determinist perspective. He favoured the latter outlook in the historiosophical, ethical, and political realms, and he employed it whenever he wanted to stress the autonomy of politics from economics. ${ }^{2}$ The same tension was present in his now controversial attempts at solving the contradictions between individual freedom and freedom in a community, and the antinomy between power and voluntary compromise.

Many writers are critical of Bauer's political activism. Ellenbogen, Wandruszka, and Butterwegge explain the schisms of his politics by way of a conflicted personality - that is, the divergence between thought and action, apparent in his attitude toward revolution, coalition, democracy, and dictatorship. ${ }^{3}$ Leser accuses Bauer of acting in a politically half-baked manner, which, according to him, became apparent during periods of increasing social pressures and conflicts, e.g. war, revolution, and the fascist offensive. Moreover, he criticises Bauer for consciously oscillating between programmatic minimalism and maximalism. Finally, he blames Bauer for the sDAP's erratic political line. ${ }^{4}$ In my view, these charges do a disservice to Bauer. Ultimately, they subjectively presume an

2 Of all analysts of Bauer's thought, only Saage developed this aspect of his historiosophy. I wish to stress, however, that we arrived at our convergent conclusions independently. Saage writes: 'In fact, no Marxist of the Second International before or after World War I emphasised the importance of the "subjective factor" as strongly as Bauer did' - Saage 199ob, p. 56 .

3 See Ellenbogen 1980, p. 1095; Wandruszka 1954, p. 451; and Butterwegge 1981, pp. 61-71.

4 See Leser 1968, p. 304. 
individual's freedom of political action, while leaving aside the complex sociohistorical reality in which Bauer had to make decisions. ${ }^{5}$

It is not easy to pass judgement on Bauer's strategy and tactics. It seems more likely to me that the inadequacy of his theoretical and practical answers resulted from his excessive dependency on Marxian discourse and thought patterns, many of which did not correspond to social realities of Marx's time. A good example (and here I agree with Leser) was Bauer's belief in the mechanisms of history and the automatism of capitalist development, from which he concluded that socialism was historically inevitable. ${ }^{6}$ Hanisch's appraisal of Bauer as a politician comes closest to mine when he writes in his Otto Bauer biography:

The central problem of Bauer's politics was not so much the contradiction between theory and practice ... as a politics of 'on the one hand / on the other' ... In other words, the difference between the sharp analyst and the political practitioner who was frequently incapable of acting. ${ }^{7}$ our translation

Without a doubt, Bauer's political indecision and supposed incapability to act were greatly influenced by his exceptionally strong sense of moral responsibility, his unquestioned humanism, and his ability to foresee the course of events. His truthful assessment of the workers' activism in 1927 serves as a case in point: their anticipation of mass support for a general strike proved baseless.

Given all the criticism voiced by Austrian researchers, it is justified to wonder whether Bauer as strategist and tactician only ever committed mistakes. If one seriously considers the balance of political forces in Austria and Europe, one has to reply that he did not - the hard political realities of 1918, 1931 and 1933-8 sufficiently prove this. Let us look at the issues that provoke such severe criticism of Bauer's behaviour. In the first instance, his refusal to instigate a revolution in 1918 was based on a realistic evaluation of the political climate across Europe. Short of a victorious revolution in the West, the fate of a proletarian dictatorship in Austria would have most likely resembled that of the Hungarian and Bavarian Soviet republics. In the second instance, a Christian-Social and Social-Democratic coalition in 1931 might have been able to prevent the ascent

\footnotetext{
5 Saage holds similar views on this - see Saage 1985, p. 11.

6 See Leser 1968, p. 33.

7 Hanisch 2011, p. 13 .
} 
of the Heimwehr. However, it is questionable whether it could have smashed Nazism and countered the rise of German nationalism and anti-Semitism.

When assessing Bauer's political conduct, it is necessary to draw a line between what was advocated and what was day-to-day practice determined by socio-historical conditions and the political situation. Bauer's policies were designed to create mechanisms that would push the bourgeois state in a democratic-liberal direction. Before the rise of fascism, he succeeded in this to a considerable extent. The overriding strategic goal, socialism, never made him blind to the short-term advantages that reformist policies could bring the working class in a bourgeois state. Success came in the form of social legislation and institutions that changed the living and working conditions of the masses for the better. The living standard of the lower social classes in today's Austria is a permanent achievement of the Social-Democratic movement of the First Republic.

None of this fully absolves Bauer from responsibility for the political defeat of Austromarxism. As the SDAP's key strategist, he is chiefly at fault for stoking the masses' illusions as to the power of the workers' movement. He can also be blamed for his excessive belief in democracy's defensive mechanisms and the stability of the democratic form of government. Moreover, his belief in the superiority and cultural and political mission of the German nation led him to overrate the revolutionary strength of the German workers' movement. Bauer's revolutionary pathos was also politically harmful. ${ }^{8}$ Not that it was of any

8 Bauer's emotionally loaded speeches in parliament provoked heckles such as 'Jewish lackey' and 'Bolshevik'. Some did not stop short of physical attacks. His verbal radicalism was the reason for polarised attitudes towards him in the press. Social-Democratic papers deemed Otto Bauer the theoretical inheritor of Victor Adler. The bourgeois press - especially the Reichspost, Neue Freie Presse, and Deutschösterreichische Zeitung - painted a damning portrait of a politician out of touch with socio-political reality, capable only of viewing the world through the prism of class struggle. We might add to this a few words on Bauer's attitude to life. He was a passionate and uncompromising speaker - but only when speaking from the platform. In private, he was extraordinarily humble, timid, and not very social. When speaking to peasants and workers, he suffered from an inferiority complex typical for the bourgeois intelligentsia. Because of this, Bauer approached workers and intellectuals in different ways. Full of patience and understanding when in conversation with the former, he was far more morally demanding of the latter, and he kept them at arm's length. His contemporaries' recollections describe Bauer as someone alien to the salons, using the tram to commute to the Baroque Palace on Ballhausplatz in worn-out clothes every day. Although he was a well-known and wealthy politician, he continued to live in a modest one-bedroom flat in Kasernengasse 2, a street that still bears his name. Bauer possessed two qualities that people highly valued in Social-Democratic politicians: he did not attach any 
significance for the leaders of hostile political factions, who were well aware that there was no genuine will to act behind the revolutionary rhetoric. It did, however, mislead potential supporters of Social Democracy: a considerable part of society believed that Bauer's politics would herald civil war in Austria. This fear resulted in widespread hostility towards the SDAP and allowed the bourgeois parties to consolidate their power.

Bauer placed great importance on the moral value of his politics, and his fate incontestably demonstrates the extent to which this both drove and incapacitated his politics. His failure as a politician does not diminish the value of the ideas he served: the realisation of social partnership and the unity of progressive and democratic forces. To accomplish these ideas, one needs to extend democracy and civil liberties and abide by ideological pluralism - principles that were close to Bauer's heart.

Austromarxism, including Bauer's theory and practice, is a fragment of the history of Marxism, a part of the history of the international workers' movement, and an essential piece of the political history of Europe. The value of Austromarxist philosophical, sociological, economic, political, and cultural ideas remains the subject of research and debate. Even if history thwarted the vision of Austromarxism, this does not diminish its real gains as a political movement. ${ }^{9}$ Bauer's contribution to these gains cannot possibly be overestimated.

importance to titles, wealth, or personal advantage, and he lived according to the values he preached.

9 Some of the Austromarxists' achievements include: encouragement of theoretical and scientific interest, cultural and sport activity, education in the spirit of ideological and religious tolerance, the introduction of intellectualism into working-class and petty-bourgeois milieus, school and health reforms, social legislation, and housing and recreational facilities. 